\title{
In vitro effects of chemotherapeutants on the lobster parasite Anophryoides haemophila
}

\author{
Mark J. Novotny ${ }^{1}$, Richard J. Cawthorn ${ }^{2, *}$, Beatrice Despres ${ }^{2}$ \\ ${ }^{1}$ Department of Anatomy and Physiology, ${ }^{2}$ Department of Pathology and Microbiology, Atlantic Veterinary College. \\ University of Prince Edward Island, Charlottetown. Prince Edward Island, Canada C1A 4P3
}

\begin{abstract}
Anophryoides haemophila is a ciliated protozoan and the causative agent of bumper car disease in lobsters. An in vitro system was developed to assess the effects of chemotherapeutants on ciliate motility and morphology. Monensin, formaldehyde and pyrimethamine + sulphaquinoxaline caused a dose-dependent reduction in ciliate motility and induced cell lysis. The effects of oxytetracycline were dependent upon the incubation solution; no effect was observed on ciliates in seawater and a dose-dependent decrease in ciliate motility and cell rounding occurred in $0.8 \mathrm{M} \mathrm{NaCl}$. Amprolium had no effect on ciliate motility or morphology. This system can be used to rapidly screen antiprotozoan compounds for efficacy against $A$. haemophila prior to selecting compounds for in vivo efficacy and safety studies.
\end{abstract}

KEY WORDS: Lobsters - Anophryoides haemophila B Bumper car disease. Chemotherapeutants . In vitro testing

Anophryoides haemophila, recently described by Cawthorn et al. (1996), is a ciliated protozoan and the causal agent of 'bumper car' disease of lobsters (Bower et al. 1994). Bumper car disease can be a source of significant mortality of lobsters maintained in holding facilities (Aiken et al. 1973, Loughlin et al. 1993). Several measures to control bumper car disease have been proposed, including changes in environmental salinity or temperature, use of chemotherapeutants, and programs to minimize stress or enhance resistance of the lobster. Currently there are no known measures to effectively prevent or control bumper car disease (Bower et al. 1994).

This study focuses on identifying potentially efficacious therapeutic compounds, using a simple in vitro system to assess chemotherapeutants selected because of their efficacy against other protozoan organisms and their acceptance for use with one or more species of food-producing animals (amprolium, monensin, oxy-

-Addressee for correspondence. E-mail: cawthorn@upei.ca tetracycline, and pyrimethamine + sulphaquinoxaline: Bayley 1995). Formaldehyde is currently used in aquaculture systems to treat protozoan ectoparasites of finfish (Scott 1993)

Materials and methods. Ciliates were harvested by collecting haemolymph from infected lobsters. Haemolymph was centrifuged at $600 \times g$ for $4 \mathrm{~min}$ and ciliates were diluted in full strength artificial seawater (Instant Ocean, Aquarium Systems, Mentor, OH, USA), or $0.8 \mathrm{M} \mathrm{NaCl}$ solution. When maintained at $4^{\circ} \mathrm{C}$ in seawater, ciliates remained viable for extended periods $(\geq 2 \mathrm{mo}$ ); however, experiments were conducted within 2 to $4 \mathrm{~d}$ of collecting haemolymph. Pyrimethamine + sulphaquinoxaline $\left(42.3 \mathrm{~g} \mathrm{l}^{-1}=9.8 \mathrm{~g}\right.$ pyrimethamine + $32.5 \mathrm{~g}$ sulphaquinoxaline $\mathrm{I}^{-1}$; Quinnoxine-S, A.P.A Division of Sanofi Santé Animale Canada Inc., Victoriaville, PQ, Canada), oxytetracycline (Syndel Labs Ltd. Vancouver, BC, Canada), formaldehyde (BDH Inc. Toronto, ON, Canada), amprolium and monensin (Sigma Chemical Company, St. Louis, MO, USA) were tested for effects on ciliate motility and morphology. Dilutions of pyrimethamine + sulphaquinoxaline, amprolium and formaldehyde were made in distilled water. Oxytetracycline was dissolved in $0.9 \%$ saline or distilled water. A $10^{-1} \mathrm{M}$ solution of monensin was prepared in ethanol, from which a $10^{-2} \mathrm{M}$ solution was prepared in $50 / 50$ ethanol/water $(\mathrm{v} / \mathrm{v})$. Subsequent monensin dilutions were prepared in distilled water. Solvent control experiments were performed using the highest concentration of ethanol $(0.55 \%)$ in monensin incubations. (See Tables $2 \& 3$ for final concentrations of all compounds.) Ciliate suspensions $(1.8 \mathrm{ml})$ were transferred to each well of cell culture cluster dishes (6 wells dish ${ }^{-1}$; Costar, Corning Laboratory Sciences, New York, NY, USA) and $200 \mu$ l. of stock solutions of compounds was added to each well $(35 \mathrm{~mm}$ diameter, $2 \mathrm{~mm}$ depth of medium). The final concentrations of 
ciliates, as determined with a haemocytometer, were 2.1 to $2.8 \times 10^{4} \mathrm{ml}^{-1}$. Incubation of ciliates + compounds was performed at $4^{\circ} \mathrm{C}$.

The effect of oxytetracycline was tested on ciliates in seawater and in $0.8 \mathrm{M} \mathrm{NaCl}$; all other compounds were tested against ciliates in seawater alone. Ciliates were assessed for motility and morphological changes at intervals after addition of the test compounds using an inverted microscope with phase contrast illumination (Nikon Model TMS, Nikon Canada Instruments Inc., Dartmouth, NS, Canada). A single observer (M.J.N.), blinded to the concentration of the compound in each culture well, performed all observations. A 3-point motility scoring system was established as defined in Table 1. Motility was assessed for each well at $40 x$ magnification by scanning 3 to 5 widely separated fields. Similarly, a 3-point morphologic scoring system was established (Table 1) and morphology was evaluated for each well at $100 \times$ magnification by examining 3 to 5 widely separated fields. Prior to scanning, each culture dish was gently rocked to ensure uniform distribution of ciliates through the medium.

Results. Morphological changes in response to chemotherapeutants ranged from no change (Fig. 1) to

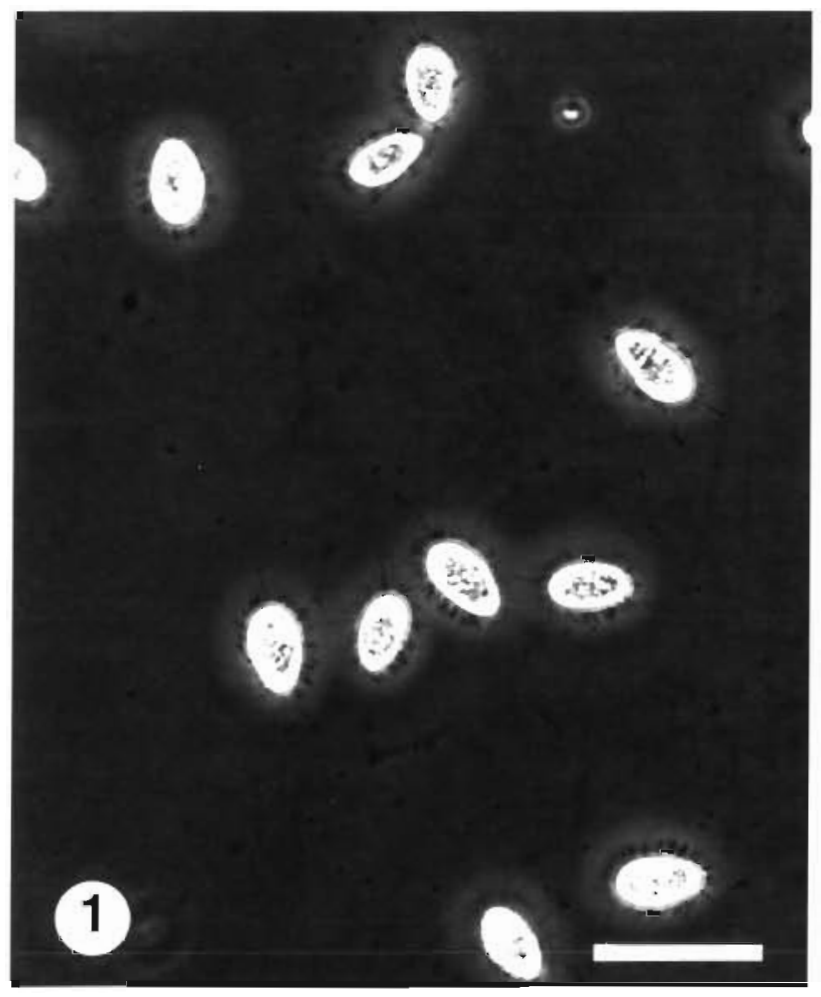

Fig. 1. Anophryoides haemophila, in vitro. Normal appearance of ciliates, time $=0$, at addition of pyrimethamine + sulphaquinoxaline $\left(42.3 \mu \mathrm{g} \mathrm{ml}^{-1}\right)$. Phase contrast illumination. Scale bar $=60 \mu \mathrm{m}$
Table 1. Scoring system for assessing compounds for in vitro efficacy against Anophryoides haemophila

\begin{tabular}{|cl|}
\hline $\begin{array}{c}\text { Motility score } \\
0\end{array}$ & $\begin{array}{l}\text { No effect on motility; cilates are highly } \\
\text { motile with many moving across the } \\
\text { microscopic field } \\
\text { Low to moderate motility; cilia movement } \\
\text { present with no or very few ciliates } \\
\text { moving across the microscopic field }\end{array}$ \\
$\begin{array}{l}\text { No evidence of motility } \\
2\end{array}$ & $\begin{array}{l}\text { No evidence of morphological changes; } \\
\text { ciliates retain elliptical shape }\end{array}$ \\
1 & $\begin{array}{l}\text { Majority of ciliates in the microscopic } \\
\text { field are round with little or no lysis } \\
\text { Extensive lysis; few or no intact cells } \\
\text { evident in all microscopic fields }\end{array}$ \\
\hline
\end{tabular}

cell rounding (Fig. 2) and lysis (Fig. 3). The effects of the compounds on ciliate motility and morphology are summarized in Tables $2 \& 3$.

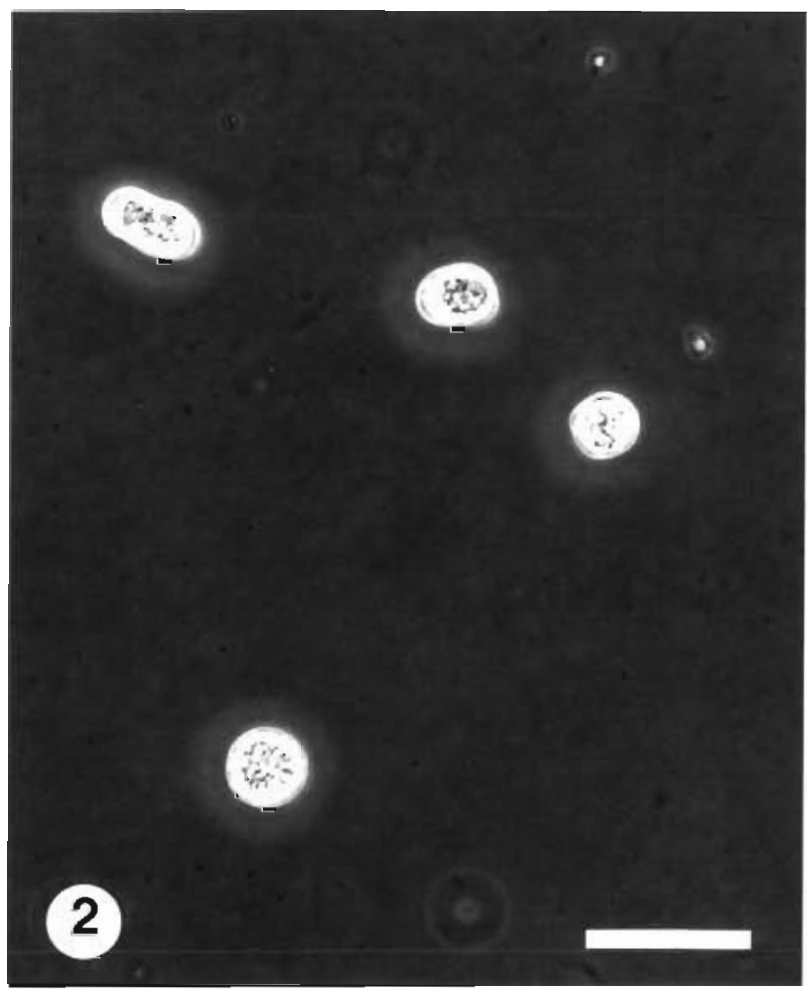

Fig. 2. Anophryoides haemophila, in vitro. Some ciliates are 'rounding up'; others have distorted oblong shapes. Time = 5 min after addition of pyrimethamine + sulphaqumoxaline $\left(42.3 \mu \mathrm{g} \mathrm{ml}^{-1}\right)$. Phase contrast illumination. Scale bar $=60 \mu \mathrm{m}$ 


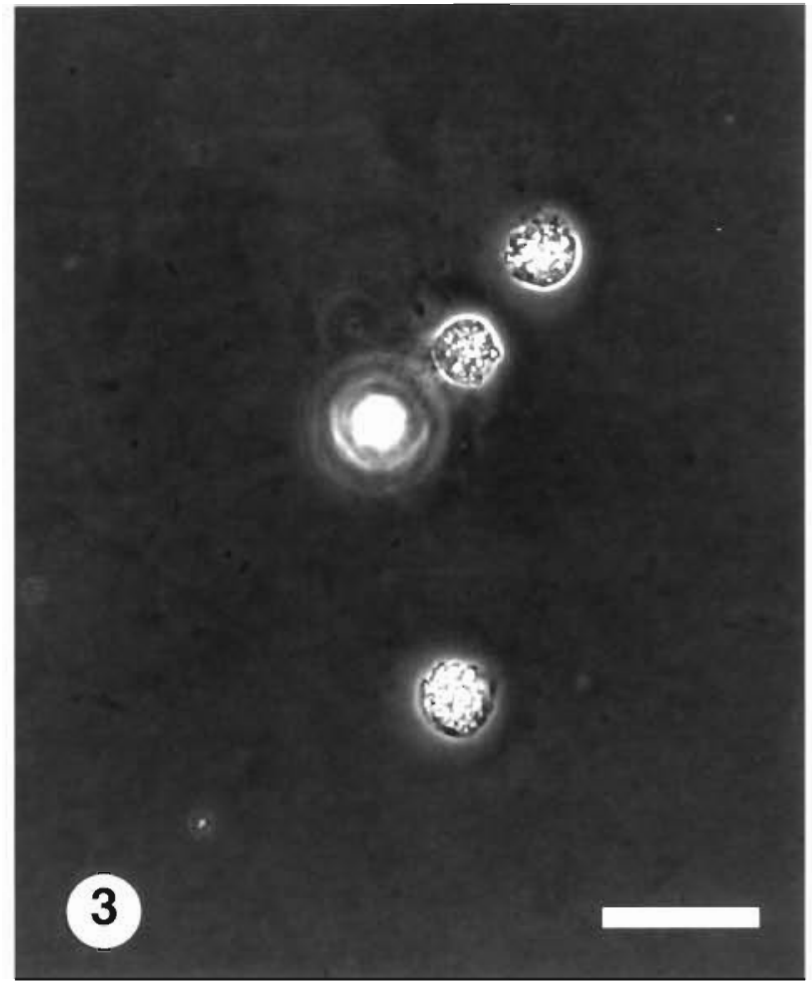

Fig. 3. Anophryoides haemophila, in vitro. Lysıs of ciliates at time $=20$ min after addition of pyrimethamine + sulphaquinoxalıne $\left(42.3 \mu \mathrm{g} \mathrm{ml}^{-1}\right)$. Phase contrast illumination. Scale bar $=$ $60 \mu \mathrm{m}$
No effects on either motility or morphology were observed with amprolium; formaldehyde, at $10^{-2}$ and $10^{-3} \mathrm{M}$, completely stopped motility within $20 \mathrm{~min}$ (Table 2). Morphological changes, characterized chiefly as cell rounding, occurred in response to these concentrations of formaldehyde. Absence of motility was observed at $20 \mathrm{~min}$ with $10^{-4} \mathrm{M}$ monensin (Table 2). Lysis was complete at 240 min with this concentration while $10^{-5} \mathrm{M}$ monensin had lesser effects on motility and morphology. Ethanol at $0.55 \%$ (solvent control) had no effect on the ciliates (data not shown). Pyrimethamine + sulphaquinoxaline at 42.3 and $423 \mu \mathrm{g}$ $\mathrm{ml}^{-1}$ induced complete cessation of motility and cell lysis, while at $4.23 \mu \mathrm{g} \mathrm{ml}^{-1}$ motility ceased at $60 \mathrm{~min}$ and morphological changes (chiefly cell rounding) were present at $\geq 60$ min (Table 3 ). Oxytetracycline had no effect on ciliates in seawater but ciliates in $0.8 \mathrm{M}$ $\mathrm{NaCl}$ were consistently less motile (Table 3 ); $10^{-3} \mathrm{M}$ oxytetracycline was lethal to ciliates in $0.8 \mathrm{M} \mathrm{NaCl}$.

Discussion. Advantages of this rapid bioassay system include: (1) use of a test organism isolated directly from the host; (2) culture of the organism in artificial seawater; (3) simultaneous assessment of different dilutions of chemotherapeutants; and (4) assessment of test compounds for different exposure times (Alderman 1982). A disadvantage of the system is that it does not permit removal of the compound from the ciliate. With continuous drug exposure, however, compounds causing no effect on ciliate motility or morphology are

Table 2. In vitro effects of amprolium, formaldehyde and monensin on motility and morphology of Anophryoides haemophila. Each value represents the mean of 4 replicate experiments except for formaldehyde, for which $n=7$ for all concentrations except $10^{-7} \mathrm{M}(\mathrm{n}=3)$ and $10^{-2} \mathrm{M}(\mathrm{n}=4)$

\begin{tabular}{|c|c|c|c|c|c|c|}
\hline \multirow[t]{2}{*}{ Compound } & \multirow{2}{*}{$\begin{array}{c}\text { Concentration } \\
\text { (M) }\end{array}$} & \multicolumn{5}{|c|}{ Motility/morphology scores at time: } \\
\hline & & $5 \mathrm{~min}$ & $20 \min$ & $60 \mathrm{~min}$ & $120 \mathrm{~min}$ & $240 \mathrm{~min}$ \\
\hline \multirow[t]{6}{*}{ Amprolium } & 0 & $0.0 / 0.0$ & $0.0 / 0.0$ & $0.0 / 0.0$ & $0.0 / 0.0$ & $0.0 / 0.0$ \\
\hline & $10^{-7}$ & $0.0 / 0.0$ & $0.0 / 0.0$ & $0.0 / 0.0$ & $0.0 / 0.0$ & $0.0 / 0.0$ \\
\hline & $10^{-6}$ & $0.0 / 0.0$ & $0.0 / 0.0$ & $0.0 / 0.0$ & $0.0 / 0.0$ & $0.0 / 0.0$ \\
\hline & $10^{-5}$ & $0.0 / 0.0$ & $0.0 / 0.0$ & $0.0 / 0.0$ & $0.0 / 0.0$ & $0.0 / 0.0$ \\
\hline & $10^{-4}$ & $0.0 / 0.0$ & $0.0 / 0.0$ & $0.0 / 0.0$ & $0.2 / 0.0$ & $0.2 / 0.0$ \\
\hline & $10^{-3}$ & $0.0 / 0.2$ & $0.0 / 0.0$ & $0.0 / 0.0$ & $0.0 / 0.0$ & $0.0 / 0.0$ \\
\hline \multirow[t]{7}{*}{ Formaldehyde } & 0 & $0.0 / 0.0$ & $0.0 / 0.0$ & $0.0 / 0.0$ & $0.1 / 0.0$ & $0.1 / 0.0$ \\
\hline & $10^{-7}$ & $0.3 / 0.0$ & $0.0 / 0.0$ & $0.0 / 0.0$ & $0.0 / 0.0$ & $0.0 / 0.0$ \\
\hline & $10^{-6}$ & $0.1 / 0.0$ & $0.0 / 0.0$ & $0.1 / 0.0$ & $0.1 / 0.0$ & $0.0 / 0.0$ \\
\hline & $10^{-5}$ & $0.1 / 0.0$ & $0.3 / 0.0$ & $0.3 / 0.0$ & $0.3 / 0.0$ & $0.3 / 0.1$ \\
\hline & $10^{-4}$ & $0.3 / 0.1$ & $0.3 / 0.1$ & $0.3 / 0.1$ & $0.6 / 0.1$ & $0.4 / 0.1$ \\
\hline & $10^{-3}$ & $0.8 / 0.1$ & $2.0 / 0.1$ & $2.0 / 0.5$ & $2.0 / 0.9$ & $2.0 / 1.3$ \\
\hline & $10^{-2}$ & $1.2 / 0.2$ & $2.0 / 1.0$ & $2.0 / 1.0$ & $2.0 / 1.0$ & $2.0 / 1.4$ \\
\hline \multirow[t]{6}{*}{ Monensin } & 0 & $0.2 / 0.0$ & $0.0 / 0.0$ & $0.0 / 0.0$ & $0.0 / 0.0$ & $0.0 / 0.0$ \\
\hline & $10^{-8}$ & $0.0 / 0.0$ & $0.0 / 0.0$ & $0.0 / 0.0$ & $0.0 / 0.0$ & $0.0 / 0.0$ \\
\hline & $10^{-7}$ & $0.0 / 0.0$ & $0.0 / 0.0$ & $0.0 / 0.0$ & $0.0 / 0.0$ & $0.0 / 0.0$ \\
\hline & $10^{-6}$ & $0.2 / 0.0$ & $0.0 / 0.0$ & $0.0 / 0.0$ & $0.5 / 0.0$ & $0.0 / 0.0$ \\
\hline & $10^{-5}$ & $0.5 / 0.0$ & $0.5 / 0.0$ & $0.5 / 0.5$ & $0.0 / 0.2$ & $0.5 / 0.4$ \\
\hline & $10^{-4}$ & $1.5 / 0.2$ & $2.0 / 1.0$ & $2.0 / 1.5$ & $2.0 / 1.8$ & $2.0 / 2.0$ \\
\hline
\end{tabular}


Table 3. In vitro effects of oxytetracycline and pyrimethamine + sulphaquinoxaline (1:3.3) on motility and morphology of Anophryoides haemophila. Each value represents the mean of 4 replicate experiments

\begin{tabular}{|c|c|c|c|c|c|c|}
\hline \multirow[t]{2}{*}{ Compound } & \multirow[t]{2}{*}{ Concentration } & \multicolumn{5}{|c|}{ Motility/morphology scores at time: } \\
\hline & & $5 \mathrm{~min}$ & $20 \mathrm{~min}$ & $60 \mathrm{~min}$ & $120 \mathrm{~min}$ & $240 \mathrm{~min}$ \\
\hline \multirow{6}{*}{$\begin{array}{l}\text { Oxytetracycline } \\
\text { (seawater) }\end{array}$} & $0 \mathrm{M}$ & $0.0 / 0.0$ & $0.0 / 0.0$ & $0.0 / 0.0$ & $0.2 / 0.0$ & $0.0 / 0.0$ \\
\hline & $10^{-7} \mathrm{M}$ & $0.0 / 0.0$ & $0.0 / 0.0$ & $0.0 / 0.0$ & $0.0 / 0.0$ & $0.0 / 0.0$ \\
\hline & $10^{-6} \mathrm{M}$ & $0.0 / 0.0$ & $0.0 / 0.0$ & $0.0 / 0.0$ & $0.0 / 0.0$ & $0.0 / 0.0$ \\
\hline & $10^{-5} \mathrm{M}$ & $0.0 / 0.0$ & $0.0 / 0.0$ & $0.0 / 0.0$ & $0.0 / 0.0$ & $0.0 / 0.0$ \\
\hline & $10^{-4} \mathrm{M}$ & $0.0 / 0.0$ & $0.0 / 0.0$ & $0.0 / 0.0$ & $0.0 / 0.0$ & $0.0 / 0.0$ \\
\hline & $10^{-3} \mathrm{M}$ & $0.0 / 0.0$ & $0.0 / 0.0$ & $0.0 / 0.0$ & $0.0 / 0.0$ & $0.0 / 0.0$ \\
\hline \multirow{6}{*}{$\begin{array}{l}\text { Oxytetracycline } \\
(0.8 \mathrm{M} \mathrm{NaCl})\end{array}$} & $0 \mathrm{M}$ & $0.5 / 0.0$ & $1.0 / 0.0$ & $1.0 / 0.0$ & $1.0 / 0.0$ & $1.0 / 0.0$ \\
\hline & $10^{-7} \mathrm{M}$ & $1.0 / 0.0$ & $1.0 / 0.0$ & $1.0 / 0.0$ & $1.0 / 0.0$ & $1.0 / 0.0$ \\
\hline & $10^{-6} \mathrm{M}$ & $1.0 / 0.0$ & $1.0 / 0.0$ & $1.0 / 0.0$ & $1.0 / 0.0$ & $1.0 / 0.0$ \\
\hline & $10^{-5} \mathrm{M}$ & $0.8 / 0.0$ & $1.0 / 0.0$ & $1.0 / 0.0$ & $1.0 / 0.0$ & $1.0 / 0.0$ \\
\hline & $10^{-4} \mathrm{M}$ & $0.0 / 0.0$ & $0.8 / 0.0$ & $1.0 / 0.0$ & $1.0 / 0.0$ & $1.0 / 0.0$ \\
\hline & $10^{-3} \mathrm{M}$ & $2.0 / 0.5$ & $2.0 / 0.9$ & $2.0 / 1.0$ & $2.0 / 1.0$ & $20 / 1.0$ \\
\hline \multirow{6}{*}{$\begin{array}{l}\text { Pyrimethamine + } \\
\text { sulphaquinoxaline }\end{array}$} & $0.0 \mu \mathrm{g} \mathrm{ml}^{-1}$ & $0.0 / 0.0$ & $0.0 / 0.0$ & $0.0 / 0.0$ & $0.0 / 0.0$ & $0.2 / 0.0$ \\
\hline & $0.04 \mu \mathrm{g} \mathrm{ml}^{-1}$ & $0.0 / 0.0$ & $0.0 / 0.0$ & $0.0 / 0.0$ & $0.2 / 0.0$ & $0.0 / 0.0$ \\
\hline & $0.42 \mu \mathrm{g} \mathrm{ml} \mathrm{m}^{-1}$ & $0.0 / 0.0$ & $0.0 / 0.0$ & $0.0 / 0.0$ & $0.0 / 0.0$ & $0.2 / 0.0$ \\
\hline & $4.23 \mu \mathrm{g} \mathrm{ml}^{-1}$ & $0.2 / 0.0$ & $0.5 / 0.2$ & $2.0 / 0.6$ & $2.0 / 0.8$ & $2.0 / 1.2$ \\
\hline & $42.3 \mu \mathrm{g} \mathrm{ml} \mathrm{m}^{-1}$ & $2.0 / 1.5$ & $2.0 / 2.0$ & $2.0 / 2.0$ & $2.0 / 2.0$ & $2.0 / 2.0$ \\
\hline & $423 \mu \mathrm{g} \mathrm{ml} \mathrm{I}^{-1}$ & $2.0 / 2.0$ & $2.0 / 2.0$ & $2.0 / 2.0$ & $2.0 / 2.0$ & $2.0 / 2.0$ \\
\hline
\end{tabular}

unlikely to have practical value. Chemotherapeutants with demonstrated in vitro efficacy should be assessed for in vivo efficacy and safety.

When studying chemotherapeutants for use in the fishing industry, Meyer (1989) recommended testing compounds already approved for use in other food animal species such as cattle, swine or poultry. Alderman (1982) listed criteria for compound selection during in vitro efficacy studies for fisheries chemotherapeutants. These include drug availability relative to manufacturing and economic factors and lack of obvious disadvantages and conflicting prior interests. All compounds tested had some level of activity against protozoan organisms and are approved in Canada for use with other food animal species and some are currently used in aquaculture systems. Oxytetracycline, currently approved for control of gaffkemia in lobsters (Terramycin-Aqua, Pfizer Canada Inc., London, ON), has antiprotozoan activity and is also used to treat anaplasmosis in cattle and Haemobartonella in cats (McDougald \& Roberson 1988, Papich 1995). Formaldehyde is currently approved for use as a parasiticide and fungicide on salmonids (Bayley 1995). Pyrimethamine + suiphaquinoxaline is approved for prevention and treatment of coccidiosis in chickens and turkeys. Monensin and amprolium are similarly approved for chickens, turkeys and cattle.

During the $4 \mathrm{~h}$ of exposure to amprolium, ciliates were not affected by this drug. Formaldehyde was effective against ciliates in concentrations used to treat ectoparasitic infections of fish (167 to $250 \mathrm{ppm}$ or approximately $10^{-3} \mathrm{M}$; Scott 1993). Since Anophryoides haemophila is principally a disease of the haemolymph of lobsters (Bower et al. 1994), formaldehyde may not be effective in treating infected lobsters, but may be useful as a surface or environmental control agent in lobster holding facilities.

Monensin and pyrimethamine + sulphaquinoxaline were effective and deserve further evaluation of in vivo efficacy and safety. The response of Anophryoides haemophila to oxytetracycline was dependent upon the incubation solution. Oxytetracycline had no effect on motility or morphology of ciliates when the reaction medium was seawater. Ciliates in $0.8 \mathrm{M} \mathrm{NaCl}$, however, became non-motile and round in response to $10^{-3} \mathrm{M}$ oxytetracycline. Seawater divalent cations (calcium and magnesium) could chelate oxytetracycline and prevent an antiparasitic effect. Or, A. haemophila may be more susceptible to oxytetracycline in $0.8 \mathrm{M}$ $\mathrm{NaCl}$. Ciliates were clearly less motile in $0.8 \mathrm{M} \mathrm{NaCl}$ compared with their matility in seawater. Although $0.8 \mathrm{M} \mathrm{NaCl}$ has the same osmolality as seawater, absence of other ions may render ciliates less motile and possibly more susceptible to oxytetracycline, or the susceptibility to oxytetracycline may be a function of $\mathrm{pH}$ differences between $0.8 \mathrm{M} \mathrm{NaCl}(\mathrm{pH}$ 6.1) and artificial seawater ( $\mathrm{pH} 7.8$ to 8.0 ).

Since Anophryoides haemophila is highly motile in seawater at $4^{\circ} \mathrm{C}$, changes in motility may represent a subtle or early drug effect. The morphological changes (cell rounding and lysis) are consistent with death of 
the ciliate and may represent a more overt or late drug effect. For concentrations of formaldehyde, monensin and oxytetracycline (in $0.8 \mathrm{M} \mathrm{NaCl}$ ) having a drug effect, marked changes in motility scores preceded marked changes in morphologic scores.

Loughlin et al. (1993) reported that sulphaguanidine and quinacrine demonstrated in vitro efficacy against Anophryoides haemophila in lobster haemolymph:seawater (50:50 v/v). Sulphapyridine, an approved drug. was less effective, as were those banned for food substances, furazolidone and metronidazole. How drug response was assessed was not described. Further, the temperature of the medium was allowed to increase from $1{ }^{\circ} \mathrm{C}$ to $20-22^{\circ} \mathrm{C}$ during drug exposure.

In conclusion, the role of chemotherapeutants in controlling or preventing bumper car disease has not been defined but chemotherapy is an alternative. Our system can be used to screen rapidly other antiprotozoan compounds and those demonstrating in vitro efficacy can be further evaluated for in vivo efficacy and safety.

Acknowledgements. Project funding, at the Atlantic Veterinary College, University of Prince Edward 1sland, was a subcontract from the Canadian Atlantic Lobster Promotion Association (CALPA). CALPA was supported in part by the Industral Research Assistance Program (Technology Enhancement) of the National Research Councll of Canada.

Responsible Subject Editor: J. E. Stewart, Dartmouth, Nova Scotia, Canada

\section{LITERATURE CITED}

Aiken DE, Sochasky JB, Wells PG (1973) Ciliate infestation of the blood of the lobster Homarus americanus. Int Counc Explor Sea, Shellfish Benthos Comm Rep CM 1973/K:46

Alderman DJ (1982) In vitro testing of fisheries chemotherapeutants. J Fish Dis 5:113-123

Bayley A (1995) Compendium of veterinary products. North American Compendiums Ltd, Hensall, ON

Bower SM, McGladdery SE, Price IM (1994) Synopsis of infectious diseases and parasites of commercially exploited shellfish. A Rev Fish Dis 4:1-199

Cawthorn RJ, Lynn DH, Despres B, MacMillan R, Maloney R, Loughlin M, Bayer R (1996) Description of Anophryoides haemophila n. sp. (Scuticociliatida: Orchitophryidae), a pathogen of American lobsters Homarus americanus. Dis Aquat Org 24:143-148

Loughlin MB, Bayer RC. Prince DL (1993) Ciliated protozoan disease in lobster, Homarus americanus. Irish-American technical exchange in the aquaculture of abalone, sea urchins, lobsters and kelp. CT-SG-93-05, Connecticut Sea Grant College Program, p 65-67

McDougald LR, Roberson EL (1988) Antiprotozoan drugs. In: Booth NB, McDonald LE (eds) Veterinary pharmacology and therapeutics, 6th edn. Lowa State University Press, Ames, p 950-968

Meyer FP (1989) Solutions to the shortage of approved fish therapeutants. J Aquat Anim Health 1:78-80

Papich MG (1995) Antimicrobial drugs. In: Ettinger SJ, Feldman EC (eds) Textbook of veterinary internal medicine, 4 th edn. WB Saunders Co, Philadelphia, p 272-284

Scott P (1993) Therapy in aquaculture. In: Brown L (ed) Aquaculture for veterinarians. Pergamon Press, Oxford, $p$ $131-152$

Manuscript first received: July 11, 1995

Revised version accepted: October 30,1995 